\title{
PENERAPAN HUKUM PROGRESIF DALAM PERKARA PENGGUNAAN DOPING ALTET DI INDONESIA
}

\author{
Sandey Tantra Paramitha \\ Departemen Pendidikan Kesehatan dan Rekreasi \\ Universitas Pendidikan Indonesia \\ Email: sandeytantra18@upi.edu \\ Hilal Ramdhani \\ Departemen Pendidikan Kewarganegaraan \\ Universitas Pendidikan Indonesia \\ Email : hilal.ramdhani18@gmail.com
}

\begin{abstract}
ABSTRAK
Olahraga erat kaitanyya dengan persaingan untuk mendapatkan kemenangan, akan tetapi dalam prakteknya beberapa atlet menggunakan doping disengaja maupun tidak disengaja, perbuatan tersebut merupakan pelangaran terhadap hukum formil, sehingga perlu adanya penegakan hukum yang adil. Penelitian ini menggunakan penelitian yuridis-normatif untuk mengetahui keadaan hukum dan konsep yang sesuai dengan pendekatan hukum progresif. Hasil penelitian menunjukan bahwa atlet yang menggunakan doping diberikan hukuman oleh hakim berdasarkan hukum formil tanpa melihat kehendak warga negara sebagai pemegang kedaulatan tertinggi.
\end{abstract}

Kata kunci: Doping, Hukum Progresif, Olahraga

\section{ABSTRACT}

Sport is closely associated with competition for victory, but in practice some athletes use intentional or unintentional doping, the act is a violation of formal law, so there needs to be fair law enforcement. This research uses juridical-normative research to know the state of law and concept in accordance with the approach of progreif law. The results showed that athletes who use doping are given punishment by judges based on formal law without seeing the will of the citizens as the highest sovereign holders. 
Keywords: Doping, Progressive Law, Sport.

\section{PENDAHULUAN}

Olahraga merupakan tempat di mana adanya proses interaksi antar manusia serta mengandung nilainilai etika satu dengan lain diperlihatkan, diuji dan dipelajari (Widyanti, 2015). Kegiatan olahraga merupakan hal yang sangat kompleks, karena dituntut untuk menerapkan nilai sportivitas, kejujuran dan kemenangan (Rahmadyansyah, 2015).

Pada tataran praktis, setiap atlet berusaha untuk menjadi pemenang dalam setiap kejuaraan (Hadi, 2011). Akan tetapi, dalam beberapa kasus, atlet menggunakan cara-cara yang tidak sesuai dengan aturan hukum dalam proses menjadi pemenang kejuaraan, salah satunya adalah penggunaan doping (Nicholls, Madigan, Backhouse, \& Levy, 2017). Hal tersebut dikarenakan persaingan prestasi olahraga yang semakin ketat membuat sebagian atlet sering menghalalkan berbagai cara. Hal ini senada dengan pernyataan (Mujika, 2017) bahwa "in winning, sometimes lifted athletes justify a variety of ways that are not good" artinya dalam meraih juara, terkadang seorang atlet menghalalkan berbagai cara yang tidak baik.

Adapun alasan pelarangan doping dalam olahraga meliputi: Pertama, alasan etis. Penggunaan doping melanggar norma fairplay dan sportivitas yang merupakan jiwa olahraga. Kedua, Alasan medis karena membahayakan keselamatan dan keselamatan pemakainya. Atlet akan mengalami habituation (kebiasaan) dan addiction (ketagihan) serta drugs abuse (ketergantungan obat) yang dapat membahayakan jiwa. (Barkoukis, Lazuras, \& Harris, 2015) menyatakan bahwa "the use of doping can endanger the health of athletes, even in some cases to result in death" artinya penggunaan doping dapat membahayakan kesehatan atlet, bahkan dalam beberapa kasus sampai mengakibatkan kematian. Alasan tidak diperbolehkannya doping dalam olahraga sangat sesuai dengan etika hukum yang bercirikan tidak boleh adanya tindakan yang merugikan orang lain, sehingga "athletes eho get caught using doping will be subject 
to legal sanctions" artinya atlet yang kedapatan menggunakan doping akan dikenai sanksi hukum (Alquraini \& Auchus, 2016).

Pada tataran hukum, penggunaan doping termasuk dalam pelanggaran hukum pidana (Busroh, 2013). Terjadinya tindak pidana, terkait jenis dan namanya dalam terminologi hukum, merupakan peristiwa yang di dalamnya terjadi pelanggaran oleh seseorang terhadap hak dan kepentingan orang lain yang menyebabkan terjadinya kerugian, baik kerugian yang bersifat materiil-kebendaan ataupun kerugian yang bersifat immateriilnon kebendaan (Soeharno, SH, 2012).

Kerugian yang dialami oleh orang lain akibat perilaku dari seseorang, mengharuskan seseorang tersebut menjalani proses hukum (Kurniawan, 2017). Perlu diketahui, terdapat karakteristik yang berbeda dalam perkara doping, seperti yang di sampaikan oleh bahwa "different characteristics in the handling of the user doping" artinya bahwa perbedaan karakteristik perkara penanganan pengguna goping (Barbosa, Garcia, Robillard, \& Jakobus, 2016). Karena akan berkaitan dengan kepentingan nasional dan daerah, sehingga dalam perkara doping aspek yang perlu diperhatikan yaitu memandang hukum tidak secara normatif, akan tetapi lebih melihat pada kehendak rakyat (Ritonga, 2011).

Realitas penegakan hukum melalui sistem peradilan pidana saat ini masih didominasi oleh cara berpikir legisme, cara penegakan hukum (pidana) yang hanya bersandarkan kepada peraturan perundang-undangan semata (Sanyoto, 2008). Sehingga mengabaikan kehendak rakyat dalam mengambilan keputusan, secara filosofis hal tersebut mengabaikan rakyat sebagai pemegang kedaulatan tertinggi di Indonesia (Ridlwan, 2012).

Permasalahan pengambilan keputusan oleh hakim yang hanya terfokus pada aturan perundangundangan mengakibatkan perlu adanya pendekatan baru dalam pengambilan keputusan oleh hakim (Khoiriah, 2013), salah satu pendekatannya yaitu melalui pendekatan hukum progresif yang memberikan kesempatan kepada rakyat untuk menemukan sendiri bagaimana keadilan itu ditegakkan (Maulidi, 2015). Artinya, tidak 
hanya pengadilan saja yang berwenang mengadili dan memutus suatu perkara, tetapi rakyat pun dapat juga melakukan hal itu (Elly Noviati, 2013). Pendekatan hukum progresif ini tidak ditujukan untuk memberikan imunitas terhadap perkara atlet yang menggunakan doping, akan tetapi sebagai bentuk penegakan hukum yang disesuaikan dengan kehendak rakyat dan kepentingan nasional (Dahlan, 2011).

\section{Metode Penelitian}

Jenis dalam penelitian ini berada pada bidang hukum, yaitu penelitian yuridis-normatif yang dilakukan dengan cara meneliti bahan pustaka atau bahan sekunder (Pendit, 2016). Bahan pustaka menjadi sumber utama dalam penelitian ini, adapun sumber penelitian yang digunakan berupa peraturan perundangundangan, konsep mengenai hukum progresif dan aspek (Kurnisar, 2012). Serta penelitian yuridis-normatif ditujukan untuk melihat hal itu dalam konteks historis, maka perlu dilakukan penelusuran sumber (RUHYAT, 2013). Penggunaan metode yuridisnormatif dalam penelitian ini bersifat kualitatif deskriptif, karena data yang diperoleh kemudian dianalisis secara menyeluruh dan saling berkaitan satu dengan yang lainnya (Hayati, 2015).

\section{Pembahasan}

Doping dalam Realitas Hukum dan Olahraga di Indonesia

Doping adalah upaya meningkatkan prestasi dengan menggunakan zat atau metode yang dilarang dalam olahraga dan tidak terkait dengan indikasi medis (Hughes, 2015). Sedangkan, International Congress of sport Sciences; Olympiade Tokyo doping adalah pemberian atau penggunaan oleh peserta lomba berupa bahan yang asing bagi organisme melalui jalan apa saja atau bahan fisiologis dalam jumlah yang abnormal atau diberikan melalui jalan yang abnormal dengan tujuan meningkatkan prestasi (Budhiarta, 2009). Dari kedua pendapat tersebut menandakan bahwa doping merupakan cara yang dilakukan secara abnormal untuk tujuan mendapatkan prestasi, tentu cara tersebut merugikan orang lain, sehingga menghilangkan nilai-nilai kejujuran dan sportivitas dalam olahraga (Agency, 2015).

Jenis-jenis doping beraneka macam, namun beberapa 
diantaranya merupakan obat yang dilarang pemakaiannya oleh pemerintah baik di dalam olahraga maupun di luar olahraga (Thevis, Kuuranne, Geyer, \& Schänzer, 2017). Hal tersebut menandakan bahwa dalam konteks Indonesia, penggunaan doping tidak diperbolehkan dalam olahraga maupun kehidupan sehari-hari (Engelberg, Moston, \& Skinner, 2015).

Didasarkan pada penggunaan doping tidak normal, maka perlu adanya pendekatan hukum yang dapat menyelesaikan permasalahan tersebut (Chadès et al., 2017), karena fakta hukum menunjukan pembangunan yang tengah berlangsung di Indonesia (Kushidayati, 2014). Hal tersebut menandakan bahwa, tindakan pemerintah yang bertujuan untuk membuat aturan terkait penggunaan doping merupakan cerminan pembangunan nasional yang sedang berlangsung (Kamber, 2011).

Pada tataran hukum nasional, sistem hukum Indonesia baik dalam lapangan hukum pidana, hukum perdata maupun hukum tata negara masih tetap menggunakan sistem hukum dan metode pendekatan sistem hukum civil law (Koloay, 2016). Sehingga dapat dipahami bahwa hukum di Indonesia bersifat ridgid karena sulit untuk adanya perubahan secara cepat, hal itu menandakan bahwa hukum jika digunakan secara normatif akan sulit mengikuti perkembangan zaman (Frenki, 2011).

Konteks hukum di Indonesia saat ini sudah mencantumkan doping sebagai pelanggaran hukum , Pasal 85 Undang - Undang Republik Indonesia Nomor 3 Tahun 2005 Tentang Sistem Keolahragaan Nasional, yang berbunyi: (1) Doping dilarang dalam semua kegiatan olahraga. (2) Setiap induk organisasi cabang olahraga dan/atau lembaga/organisasi olahraga nasional wajib membuat peraturan doping dan disertai sanksi. (3) Pengawasan doping sebagaimana dimaksud pada ayat (1) dilakukan oleh Pemerintah.

Peraturan tersebut menandakan bahwa dalam hukum formil di Indonesia, sudah sangat lengkap membuat aturan mengenai doping (Dahlan, 2011). Hal tersebut menandakan bahwa adanya political will dari pemerintah dalam mencegah tindakan-tindakan doping (Kuswandi Aos, 2012). 


\section{Pendekatan Hukum Progresif}

Persoalan hukum yang krusial adalah bagaimana caranya prinsipprinsip hukum secara filosofis, yuridis dan sosiologis sebagai asas hukum yang objektif diterjemahkan dalam undang-undang (Wahjuono, 2014). Hal tesebut menandakan bahwa dalam pembuatan undangundang perlu mempertimbangkan unsur filosofis, yuridis dan sosiologis, ketiga unsur tersebut perlu masuk dalam setiap peraturan perundang-undangan (Siregar, 2007).

Pada tataran praktis, hukum perlu mempertimbangkan nilainilai etis, agar dalam penerapannya dapat diterima oleh semua komponen masyarakat (Syariah, 2008). Asas hukum merupakan landasan atau latar belakang dari lahirnya peraturan perundangundangan, atau merupakan dasardasar pemikiran yang umum dan abstrak, serta di dalamnya terkandung nilai-nilai etis, sehingga peraturan yang lahir nantinya mengandung nilai-nilai etis (Febriansyah, 2016).

Penerapan hukum juga perlu untuk melihat unsur keadilan dalam masyarakat, karena hukum sejatinya dibentuk dan diberlakukan sebagai sarana untuk memberikan perlindungan kepada setiap orang secara berkeadilan (Christiani, 2003). Sehingga dalam penerapannya tidak bisa hanya terfokus pada hukum secara normatif, karena akan mengabaikan perlindungan kepada seluruh warga negara (Likadja, 2015).

Pendekatan hukum progresif merupakan suatu solusi dari penerapan hukum yang selama ini tidak sesuai dengan kehendak warga negara (Suwito, 2015), karena seharusnya hukum hanya menjadi pedoman di dalam menegakkan hukum, bukan sebagai aturan-aturan normatif yang harus diikuti kemauannya. Inilah yang kemudian dikenal dengan gagasan hukum progresif (Maulidi, 2015). Selain itu, dalam pendekatan hukum progresif Kejujuran dan ketulusan menjadi mahkota penegakan hukum (Perpustakaan UGM, 2003). Empati, kepedulian, dan dedikasi menghadirkan keadilan, menjadi roh penyelenggara hukum. Kepentingan manusia (kesejahteraan dan kebahagiaannya) menjadi titik orientasi dan tujuan akhir hukum. Para penegak hukum menjadi ujung 
tombak perubahan (Lasserre \& Mundt, 2017).

(Malian, 2010) hukum progresif memiliki karakteristik yang membedakannya dengan yang lain, yaitu:

Pertama, paradigma dalam hukum progresif adalah, bahwa hukum adalah untuk manusia. Kedua, hukum progresif menolak untuk mempertahankan status quo dalam berhukum. Mempertahankan status quo memberikan efek yang sama, seperti pada waktu orang berpendapat, bahwa hukum adalah tolak ukur semuanya, dan manusia adalah untuk hukum.

Ketiga, apabila diakui bahwa peradaban hukum akan memunculkan sekalian akibat dan risiko yang ditimbulkan, maka cara berhukum sebaiknya juga mengantisipasi tentang bagaimana mengatasi hambatan-hambatan dalam menggunakan hukum tertulis. Keempat, hukum progresif memberikan perhatian besar terhadap peranan perilaku manusia dalam hukum.

Keempat karakteristik tersebut menandakan bahwa fokus dari hukum progresif bukan pada aturan hukum yang bersifat normatif, akan tetapi perilaku manusia yang sesuai dalam konteks hukum. Sehingga, penerapan hukum akan sesuai dengan keadaan zaman.

\section{Penerapan Pendekatan Hukum Progresif dalam Penggunaan Doping}

Fungsi hukum dalam masyarakat adalah mempertahankan ketertiban melalui kepastian hukum dan juga hukum (sebagai kaidah sosial) harus dapat mengatur (membantu) proses perubahan dalam masyarakat (Hasyim Nawawie, 2013). Terdapat dua aspek dalam fungsi hukum yang senantiasa berada dalam kehidupan masyarakat, yaitu kepastian hukum dan mengatur perubahan masyarakat menuju arah yang lebih baik. Kedua fungsi ini seharusnya perlu menjadi perhatian yang serius dari setiap elemen dalam negara (Ritonga, 2011).

Hukum Pidana dalam perkembangannya ternyata semakin banyak digunakan dan diandalkan dalam rangka mengatur dan menertibkan masyarakat melalui peraturan perundangundangan (Yarni \& Amir, 2014). Sehingga hukum pidana merupakan aspek yang sangat penting bagi perkembangan negara, terutama 
untuk dapat mengontrol dan menertibkan masyarakat (Yahya, 2005).

Pendekatan hukum progresif tidak bisa mengabaikan keadaan hukum formil yang berlaku, sehingga hukum formil di Indonesia harus sesuai dengan asas-asas hukum (Rasul, 2009). Dalam teori perundang-undangan terdapat asas-asas hukum yang harus dipatuhi dalam pembuatan undangundang (Febriansyah, 2016), yaitu:

1. Asas yang bersumber pada politik konstitusi dan ketentuan Undang-Undang Dasar (asas konstitusional dalam penerapan hukum);

2. Asas tidak berlaku surut (nonretroaktif);

3. Asas peralihan hukum;

4. Asas pertingkatan peraturan perundang-undangan (lex superior derogat legi inferiori);

5. Asas aturan hukum yang khusus akan mengesampingkan aturan hukum yang umum (lex specialis derogat legi generali);

6. Asas aturan hukum yang baru mengesampingkan atau meniadakan aturan hukum yang lama (lex posterior derogat legi priori);
7. Asas mengutamakan atau mendahulukan hukum tertulis dari hukum tidak tertulis;

8. Asas kepatuhan, keadilan, kepentingan umum, dan ketertiban umum.

Dalam upaya untuk optimalisasi penerapan pendekatan hukum progresif, keadaan hukum formil juga harus mematuhi kedelapan asas tersebut, serta adanya kesadaran dari masyarakat untuk berperilaku sesuai dengan hukum.

Kaitannya dengan pelanggaran hukum doping di Indonesia, pendekatan yang paling efektif yaitu melalu pendekatan hukum progresif, karena Undang-Undang sebenarnya hanya syarat-syarat yang ditetapkan asosiasi politis (Marzuki, 2012). Sehingga jika bertumpu pada hukum formil secara represif, tentu akan mengakibatkan lunturnya keikutsertaan masyarakat dalam penegakan hukum (Huda, 2007). selain itu, realita dalam berhukum di Indonesia, para hakim umumnya hanya terfokus pada kepastian dan kurang mengedepankan keadilan (Wantu, 2012). Hal tersebut mengindikasikan sulitnya pemberian keadilan terhadap pengguna doping bagi atlet 
olahraga (Valkenburg, de Hon, \& Van Hilvoorde, 2014).

Secara praktik pendekatan hukum progresif untuk atlet yang menggunakan doping, harus sesuai dengan jalur hukum atau kebijakan penal (Karstedt, 2015). Akan tetapi, dalam proses pengambilan keputusan tidak bisa hanya berdasarkan hukum tertulis yang berlaku, karena sifatnya ridgid dan sulit menyesuaikan dengan keadaan zaman. Sehingga hakim harus dapat melihat kehendak rakyat dan kepentingan nasional, apalagi bila atlet tersebut mempunyai potensi untuk mengharumkan negara Indonesia.

\section{Kesimpulan}

Olahraga erat kaitanyya dengan persaingan untuk mendapkan prestasi, akan tetapi dalam prakteknya beberapa atlet menggunakan cara-cara yang tidak sesuai dengan aturan hukum yang berlaku, sehingga perlu adanya penindakan hukum. Dalam penerapan hukum, selalu terfokus pada hukum formil yang berlaku, sehingga mengabaikan kehendak rakyat dan kepentingan nasional, terutama dalam perkara doping beberapa atlet tidak ikut lagi dalam kejuaraan, padahal atlet tersebut mempunyai potensi untuk mengembangkan kemampuannya. Berdasarkan hal tersebut, maka perlu adanya pendekatan hukum yang disifat progresif yaitu dengan mempertimbangkan kehendak rakyat dalam pengambilan keputusannya.

\section{Daftar Pustaka}

Agency, W. A. D. (2015). World Anti-Doping Code. World AntiDoping, (JANUARY), 1-116. https://doi.org/10.1016/S01 40-6736(12)60080-4

Alquraini, H., \& Auchus, R. J. (2016). Strategies that athletes use to avoid detection of androgenic-anabolic steroid doping and sanctions. Molecular and Cellular Endocrinology. https://doi.org/10.1016/j.mc e.2017.01.028

Barbosa, E. A., Garcia, A., Robillard, M. P., \& Jakobus, B. (2016). Enforcing Exception Handling Policies with a Domain-Specific Language. IEEE Transactions on Software Engineering, 42(6), 559-584. https://doi.org/10.1109/TSE. 2015.2506164

Barkoukis, V., Lazuras, L., \& Harris, P. R. (2015). The effects of self- 
affirmation manipulation on decision making about doping use in elite athletes. Psychology of Sport and Exercise, 16(P2), $175-181$. https://doi.org/10.1016/j.psy chsport.2014.02.003

Budhiarta, P. (2009). Prinsip enam benar pemberian obat.

Busroh, F. F. (2013). Filsafat Pemidanaan Dalam Stelsel Pidana sebagai Upaya Pembaharuan Hukum Pidana di Indonesia. Disiplin, 17(no.04 desember 2013), 12-25.

Chadès, I., Nicol, S., Rout, T. M., Péron, M., Dujardin, Y., Pichancourt, J. B., ... Hauser, C. E. (2017). Optimization methods to solve adaptive management problems. Theoretical Ecology. https://doi.org/10.1007/s120 80-016-0313-0

Christiani, W. (2003). Hukum Sebagai Norma Sosial Memiliki Sifat Mewajibkan. Mengenal Hukum, 4, 151-167.

Dahlan, A. C. (2011). Hukum, Profesi Jurnalistik dan Etika Media Massa. Jurnal Hukum, XXV(1), 395-411.

Elly Noviati, C. (2013). Demokrasi dan Sistem Pemerintahan. Jurnal Konstitusi, 10(2), 345.
Engelberg, T., Moston, S., \& Skinner, J. (2015). The final frontier of anti-doping: A study of athletes who have committed doping violations. Sport Management Review, 18(2), 268-279. https://doi.org/10.1016/j.smr. 2014.06.005

Febriansyah, F. I. (2016). KONSEP PEMBENTUKAN PERATURAN PERUNDANG-UNDANGAN DI INDONESIA. Perspektif, 21(3), 220-229.

Frenki, F. (2011). Politik hukum dan perannya dalam pembangunan hukum di indonesia pasca reformasi. Jurnal Asas, 3(No 2 Juli 2011), 1-8.

https://doi.org/http://ejourna l.iainradenintan.ac.id/index.ph $\mathrm{p} / \mathrm{asas} /$ article/view/122

Hadi, R. (2011). Peran Pelatih dalam Membentuk Karakter Atlet. Jurnal Media Ilmu Keolahragaan Indonesia, 1(1), 88-93.

Hasyim Nawawie. (2013). Hukum Islam Dalam Perspektif SosialBudaya Di Era Reformasi. Epsiteme, 8(1), 2-28.

Hayati, N. (2015). Pemilihan Metode Yang Tepat Dalam Penelitian (Metode Kuantitatif Dan Metode Kualitatif). Jurnal 
Tarbiyah Al-Awlad, Volume IV, Edisi 1, Hlm. 345-357, 4(1), 345-357.

Huda, N. (2007). Hukum Tata Negara Indonesia. Jakarta: Raja Grafindo Persada.

Hughes, D. (2015). The world antidoping code in sport. Australian Prescriber, 38(5), 167-170.

https://doi.org/10.18773/AUS TPRESCR.2015.059

Kamber, M. (2011). Development of the role of National AntiDoping Organisations in the fight against doping: From past to future. Forensic Science International, 213(1-3), 3-9. https://doi.org/10.1016/j.fors ciint.2011.07.026

Karstedt, S. (2015). Cultural peers and penal policies: A configurational approach toward mapping penal landscapes. Punishment and Society, 17(3), 374-396. https://doi.org/10.1177/1462 474515590890

Khoiriah. (2013). Sistem Pendukung Keputusan untuk Penilaian Kinerja Dosen Menggunakan Metode Analytical Hierarchy Process (AHP). Jurnal Sistem Informasi, 1(1). $\begin{array}{cr}\text { Koloay, } & \text { R. } \\ \text { PERKEMBANGAN } & \text { HUKUM } \\ \text { INDONESIA } & \text { BERKENAAN } \\ \text { DENGAN } & \text { TEKNOLOGI } \\ \text { INFORMASI DAN KOMUNIKASI } \\ \text { Oleh: Renny NS Koloay. Jurnal } \\ \text { Hukum Unsrat, 22(5), 16-27. }\end{array}$

Kurniawan, A. (2017). Metode Kognitif dan Behavioral untuk Mengelola Stres dan Rasa Sakit Akibat Cedera pada Atlet Bola Basket. INSAN Jurnal Psikologi Dan Kesehatan Mental, 2(1), 63.

https://doi.org/10.20473/jpk m.V2I12017.63-76

Kurnisar. (2012). Pancasila Sumber Dari Segala Sumber Hukum. Jurnal Ilmiah Ilmu Sosial, 11(3), 244-253.

Kushidayati, L. (2014). THE DEVELOPMENT OF ISLAMIC LAW IN INDONESIA. Qudus International Journal of Islamic Studies, $1(2)$. https://doi.org/10.21043/QIJI S.V1I2.185

Kuswandi Aos. (2012). Membangun Gerakan Budaya Politik dalam Sistem Politik Indonesia. Jurnal Pascasarjana: GOVERNANCE, 1(1).

Lasserre, B., \& Mundt, A. (2017). Competition Law and Big Data: The Enforcers' View. Rivista 
Italiana Di Antitrust / Italian Antitrust Review, 4(1), 87-103. https://doi.org/10.12870/iar12607

Likadja, J. A. C. (2015). Memaknai "Hukum Negara (Law Through State)" dalam Bingkai "Negara Hukum (Rechtstaat)." Hasanuddin Law Review, 1(1), $75-86$.

Malian, O. S. (2010). Perkembangan Filsafat Ilmu serta Kaitannya dengan Teori Hukum. Fakultas Hukum, 38(UNISIA), 64-70.

Marzuki. (2012). Politik Pendidikan Nasional dalam Bingkai Undang-undang Sistem Pendidikan Nasional. Jurnal Penelitian Humaniora, 17(2), 16-38.

Maulidi. (2015). Paradigma Progresif dan Maqashid Syariah: Manhaj Baru Menemukan Hukum Responsif. Asy-Syir'ah, 49(2), 251-264.

Mujika, I. (2017). Quantification of training and competition loads in endurance sports: Methods and applications. International Journal of Sports Physiology and Performance. https://doi.org/10.1123/ijspp. 2016-0403

Nicholls, A. R., Madigan, D. J., Backhouse, S. H., \& Levy, A. R.
(2017). Personality traits and performance enhancing drugs: The Dark Triad and doping attitudes among competitive athletes. Personality and Individual Differences, 112, 113-116. https://doi.org/10.1016/j.paid .2017.02.062

Pendit, P. L. (2016). Penggunaan Teori dalam Penelitian.

Perpustakaan UGM, i-lib. (2003). Kajian filosofis terhadap eksistensi hukum internasional. Jurnal I-Lib UGM. Rahmadyansyah. (2015). Internalisasi Nilai-nilai Keteladanan Orang Tua pada Anak Prasekolah. Jurnal Mudarrisuna, 4(2), 763-782.

Rasul, S. (2009). Penerapan good governance di Indonesia dalam upaya pencegahan tindak pidana korupsi. Mimbar Hukum, 21(3), 538-553. https://doi.org/10.22146/jmh .16276

Ridlwan, Z. (2012). Negara Hukum Indonesia Kebalikan Nachtwachterstaat. Fiat Justisia, 5(2), 141-152. https://doi.org/https://doi.or g/10.25041/fiatjustisia.v5no2. 56

Ritonga, I. L. K. (2011). Kebijakan 
Hukum Pidana Terhadap Tindak Pidana Di Bidang Medis. Universitas Muhammadiyah Malang, 2, 14.

RUHYAT, H. (2013). Metode Penelitian Pendidikan Pendekatan Kuantitaif, Kualitatif, dan R\&D. Metode Penelitian Pendidikan Pendekatan Kuantitaif, Kualitatif, Dan R\&D, 283-393. https://doi.org/10.1007/s133 98-014-0173-7.2

Sanyoto. (2008). Penegakan hukum di indonesia. Jurnal Dinamika Hukum, 8(244), 199-204.

Siregar, C. N. (2007). Sociological analysis of corporate social responsibility implementation in Indonesia (Analisis sosiologis terhadap implementasi corporate social responsibility pada masyarakat Indonesia). Jurnal Sosioteknologi, Ed. 12 yea, 1-4.

Soeharno, SH, M. (2012). BENTURAN ANTARA HUKUM PIDANA ISLAM DENGAN HAKHAK SIPIL DALAM PERSPEKTIF HAK ASASI MANUSIA Oleh. Lex Crimen, 1(2), 83-104.

Suwito. (2015). Putusan Hakim yang Progresif dalam Perkara
Perdata (Telaah "Kasus Pohon Mangga"). Hasanuddin Law Review, 1(1), 101-113.

Syariah, R. (2008). Keterkaitan Budaya Hukum Dengan Pembangunan Hukum Nasional. Jurnal Equality, 13(1).

Thevis, M., Kuuranne, T., Geyer, H., \& Schänzer, W. (2017). Annual banned-substance review: analytical approaches in human sports drug testing. Drug Testing and Analysis. https://doi.org/10.1002/dta.2 139

Valkenburg, D., de Hon, O., \& Van Hilvoorde, I. (2014). Doping control, providing whereabouts and the importance of privacy for elite athletes. International Journal of Drug Policy, 25(2), 212-218. https://doi.org/10.1016/j.dru gpo.2013.12.013

Wahjuono, T. (2014). PERUBAHAN PENGATURAN PERUNTUKAN KAWASAN DALAM HUKUM PENATAAN RUANG ( Studi Politik Hukum Atas Kebijakan Penataan Ruang Kota Malang ). De Jure: Jurnal Hukum Dan Syar'iah, 6(2), 166-175.

Wantu, F. M. (2012). Mewujudkan Kepastian Hukum, Keadilan 
dan Kemanfaatan Dalam

Putusan Hakim di Peradilan

Perdata. Jurnal Dinamika Hukum, 12(3).

Widyanti, T. (2015). PENERAPAN NILAI-NILAI KEARIFAN LOKAL DALAM BUDAYA. Jurnal Pendidikan Ilmu Sosial, 24(2).

Yahya, N. (2005). Resensi Buku: HUKUM PIDANA. Perspektif, 2(2), 86.

Yarni, M., \& Amir, L. (2014). PENGUATAN TATA KELOLA PEMERINTAHAN YANG BAIK DALAM PEMBENTUKAN PERATURAN PERUNDANGUNDANGAN SEBAGAI PILAR PENEGAKAN HAK ASASI MANUSIA DI INDONESIA. IImu Hukum, 122-136. 